\title{
TANGGUNG GUGAT NOTARIS ATAS SUATU AKTA JAMINAN YANG HAK KEPEMILIKAN TERHADAP OBYEKNYA TIDAK SEMPURNA
}

\author{
Dela Venia Agisti \\ Fakultas Hukum Universitas Wijaya Kusuma Surabaya \\ e-mail: delaveniaagisti@gmail.com \\ Moch. Isnaeni \\ Fakultas Hukum Universitas Wijaya Kusuma Surabaya \\ e-mail: profisnaeni@gmail.com
}

\begin{abstract}
ABSTRAK
Dalam utang piutang seyogyanya perjanjian utang piutang dibuat secara tertulis. Beberapa lembaga jaminan mensyaratkan untuk menggunakan akta notaris. Walaupun tidak dipersyaratkan, perjanjian utang piutang itu tetap dapat dibuat oleh atau di hadapan notaris. Suatu akta jaminan yang dibuat oleh notaris sesuai yang dipersyaratkan sudah barang tentu menyebutkan pula obyeknya. Terdapat potensi klaim oleh orang lain atas obyek yang sedang dijaminkan tersebut sebagaimana kerap terjadi bukti kepemilikan yang ganda. Permasalahannya adalah bagaimana tanggung gugat notaris manakala terjadi hal demikian. Penelitian ini merupakan penelitian normatif. Hasil dari penelitian ini adalah notaris harus mempertanggungjawabkan segala isi dalam aktanya, termasuk keabsahan kepemilikan objeknya.
\end{abstract}

Kata Kunci: tanggung gugat; Notaris; kepemilikan

\section{ABSTRACT}

In this accounts receivable debt, the debt payable agreement should be made in writing. Some guarantee institutions require the use of a notarial deed. Althought not required, the loan agreement can still be made by or before a notary in accordance with the requirements, of course also mentions the object. There are potential claims by others for the object being pledged as proof of multiple ownership is often the case. The problem is how notary accountability occurs when such things occur. This research is a normative research. The results of this study are the notary must be able to take responsibility for all contents in the deed, including the validity of ownership of the object.

Keywords: liability; Notary; ownership

\section{PENDAHULUAN}

Notaris pada dewasa ini dinilai dan dipandang oleh masyarakat sebagai pejabat yang mampu memberikan suatu produk hukum yang mempunyai kekuatan hukum pembuktian kuat. Produk hukum ini berupa suatu akta, yang mana sudah tentu manakala itu adalah menyangkut hubungan hukum dua pihak, orientasinya adalah dalam bentuk kesepakatan.

Pada prinsipnya akta yang dibuat oleh dan/atau di hadapan Notaris harus dibuat secara sempurna dan tidak ada perubahan, baik penggantian, penambahan, 
pencoretan, penyisipan maupun bahasa akta harus sesuai dengan Bahasa Indonesia sesuai ejaan yang disempurnakan. Namun apabila di dalam akta terjadi perubahan, maka Notaris harus melakukan perubahan terhadap substansi akta. Perubahan akta tersebut dilakukan terhadap akta yang belum ditandatanagani oleh para pihak, saksi dan Notaris. Perubahan akta sebelum ditandatangani oleh para pihak, saksi dan Notaris lazim disebut dengan renvoi. Sementara itu minuta akta yang telah ditandatangani para pihak, saksi, dan Notaris, kemudian didalamnya terdapat kesalahan penulisan dan pengetikan, maka harus dilakukan pembetulan, dan akta yang sebelumnya telah ditandatangani harus dihancurkan. ${ }^{1}$

Seorang Notaris dalam menjalankan profesinya sangat dimungkinkan untuk berbuat salah, baik itu kesalahan penulisan, ataupun substansi, hanya saja untuk kesalahan penulisan dapat dibetulkan sebagaimana cara yang disebutkan di atas, akan tetapi untuk suatu kesalahan substansi ini cukup krusial bagi Notaris, mengingat setiap akta yang dibuat oleh Notaris pada dasarnya dapat dikatakan tidaklah murah. Manakala terdapat kesalahan substansi, ketika perihal dalam akta tersebut belum dilaksanakan dan/atau para pihak masih berada di hadapan Notaris, itu masih dapat dimaklumi karena ini sudah tentu sebagai bentuk koreksi oleh para pihak sebelum ditandatangani akta Notaris tersebut, oleh karenanya dapat diselesaikan sebagaimana cara diatas. Sebaliknya, manakala akta Notaris itu telah dibuat, ditandatangani, para pihak telah diberikan salinan atau turunan atau grossenya, dan juga telah dilaksanakan perihal akta tersebut, kemudian baru ditemukan adanya kesalahan substansi yang menyangkut kepastian hukum salah satu atau kedua belah pihak, ini yang cukup krusial, bahkan manakala itu membawa kerugian salah satu atau kedua belah pihak, atau bahkan pihak ketiga diluar akta tersebut, maka sudah sepatutnya pihak yang dirugikan tersebut meminta ganti rugi kepada Notaris tersebut melalui jalur hukum.

Akta Notaris dapat berupa akta otentik dan akta non otentik. Sesuai dengan pengertian akta otentik pada undang-undang, bisa diketahui bahwa akta Notaris disebut akta otentik bilamana undang-

${ }^{1}$ Habib Adjie. (2015). Tafsir Tematik Hukum Notaris Indonesia Berdasarkan Undang-Undang Nomor 2 Tahun 2014 tentang Jabatan Notaris. Bandung: Refika Aditama, h. 107. undang menunjuk Notaris untuk membuat akta tersebut. Sedangkan, akta Notaris disebut akta non otentik bilamana undang-undang telah menunjuk pejabat umum lain untuk membuat akta tersebut. Pada akta Notaris sebagaimana di atas, maka yang tidak sedikit dibuat Notaris adalah akta jaminan, pada akta jaminan, detail dari obyek yang dijaminkan adalah sangat penting sebagai aspek pembuktiannya dan keabsahan penjaminan tersebut, manakala ternyata terdapat kesalahan dalam akta Notaris itu dan merugikan pihak ketiga, terkait obyek jaminan tersebut ternyata diakui milik pihak ketiga, maka sudah barang tentu hal ini sebaiknya diselesaikan melalui jalur hukum.

\section{PERUMUSAN MASALAH}

Berdasarkan pemaparan latar belakang di atas dapat dirumuskan permasalahan yang akan dikaji dalam penelitian ini adalah tanggung gugat Notaris terhadap akta otentik yang dibuat olehnya apabila obyek jaminannya diakui oleh pihak ketiga.

\section{PEMBAHASAN}

\section{Pengaturan Tanggung Gugat Notaris Berdasarkan Hukum di Indonesia}

Suatu kesalahan dalam menjalankan profesi dapat disebabkan oleh kekurangan pengetahuan, kurang pengalaman, atau kurang pengertian. Demikian pula kesalahan Notaris dalam menjalankan jabatan kadangkala disebabkan oleh kekurangan pengetahuan Notaris terhadap persoalan yang dimintakan oleh klien baik dari aspek hukum maupun aspek lainnya. Bagi Notaris tertentu, terutama Notaris baru yang kurang pengalaman dalam persoalan yang diajukan oleh klien, maka tidak jarang terjadi kesalahan dalam menuangkan maksud dan permintaan klien dalam akta yang dibuat. Ketidakmengertian Notaris terhadap apa yang disampaikan dan diminta oleh klien juga seringkali menimbulkan kesalahan dalam pembuatan akta oleh Notaris. ${ }^{2}$

Pelanggaran atau kesalahan Notaris dalam menjalankan jabatan, dapat menimbulkan kerugian pada klien atau pihak lain. Kesalahan yang dilakukan oleh Notaris dalam menjalankan jabatan dapat membawa dampak pada akta yang dibuatnya, yakni hanya mempunyai kekuatan hukum sebagai akta di bawah tangan apabila ditandatangani oleh

2 ibid. 
orang-orang yang menghadap. Kekebalan dari akta otentik sebagai akta Notaris yang kemudian berubah atau turun derajat mejadi akta di bawah tangan dapat menyebabkan Notaris berkewajiban untuk memberikan ganti rugi. Pihak yang dirugikan akibat terjadinya pelanggaran atau kesalahan tersebut dapat mengajukan tuntutan atau gugatan kerugian kepada Notaris yang bersangkutan melalui pengadilan. ${ }^{3}$

Kedudukan akta Notaris mempunyai kekuatan pembuktian sebagai akta di bawah tangan merupakan nilai dari sebuah pembuktian yang tidak dapat dituntut rugi dalam bentuk apapun. Demikian pula dengan akta batal demi hukum maka akta tersebut dianggap tidak pernah ada atau tidak pernah dibuat. Jika demikian bahwa tuntutan biaya, ganti rugi, dan bunga bukan sebagai akibat seperti itu, tapi karena ada hubungan hukum antara Notaris dan para pihak yang menghadap Notaris. Hubungan hukum merupakan suatu hubungan yang akibatnya diatur oleh hukum. ${ }^{4}$

Ketika penghadap datang ke Notaris agar tindakan atau perbuatannya diformulasikan ke dalam akta otentik sesuai dengan kewenangan Notaris, dan kemudian Notaris membuatkan akta atas permintaan atau keinginan para penghadap tersebut, maka dalam hal ini memberkan landasan kepada Notaris dan para penghadap telah terjadi hubungan hukum. Oleh karena itu Notaris harus menjamin bahwa akta yang dibuat tersebut telah sesuai menurut aturan hukum yang sudah ditentukan, sehingga kepentingan yang bersangkutan terlindungi dengan akta tersebut. Dengan hubungan hukum seperti itu, maka perlu ditentukan kedudukan hubungan hukum tersebut yang merupakan awal dari tanggung gugat. ${ }^{5}$

Hubungan hukum antara para penghadap dengan Notaris dapat dimasukkan atau dikualifikasikan dalam bentuk sebuah wanprestasi jika terjadi hubungan hukum secara kontraktual. Misalnya, para penghadap memberi kuasa untuk melakukan suatu pekerjaan tertentu untuk dan atas nama pemberi kuasa. Para penghadap datang sendiri ke Notaris karena keinginan para penghadap sendiri, dan pada dasarnya semua Notaris terbuka untuk siapa saja,

\footnotetext{
${ }^{3}$ ibid.

${ }^{4}$ Habib Adjie. (2017). Sanksi Perdata dan Administratif Terhadap Notaris Sebagai Pejabat Publik. Bandung: Refika Aditama, h. 82.

${ }^{5}$ ibid., h. 100.
}

dan suatu hal yang tidak tepat jika setiap orang yang datang kepada Notaris terlebih dahulu harus membuat perjanjian pemberian kuasa untuk melakukan suatu pekerjaan tertentu, dalam hal ini membuat akta. Dengan tidak adanya perjanjian baik tertulis maupun tidak tertulis atau lisan yang dinyatakan secara tegas atau tidak antara Notaris dengan para pihak untuk membuat akta yang diinginkannya, maka tidak tepat jika hubungan hukum antara Notaris dan para pihak dikualifikasikan sebagai hubungan kontraktual yang jika Notaris wanprestasi dapat digugat dengan dasar gugatan Notaris telah wanprestasi. ${ }^{6}$

Inti dari suatu perbuatan melanggar hukum, yaitu tidak ada hubungan kontraktual antara satu pihak dengan pihak lainnya. Notaris melakukan suatu pekerjaan berdasarkan kewenangannya atau dalam ruang lingkup tugas jabatan sebagai Notaris berdasarkan Undang-Undang Nomor 2 Tahun 2014 tentang Perubahan Atas Undang-Undang Nomor 30 Tahun 2004 tentang Jabatan Notaris (selanjutnya disebut UUJN). Para penghadap datang kepada Notaris atas kesadaran sendiri dan mengutarakan keinginannya dihadapan Notaris, yang kemudian dituangkan dalm bentuk akta Notaris sesuai aturan hukum yang berlaku. Sepanjang Notaris melaksanakan tugas jabatannya sesuai UUJN, dan telah memenuhi semua tata cara dan persyaratan dalam pembuatan akta, maka akta yang bersangkutan telah pula sesuai dengan kehendak para pihak yang menghadap Notaris, oleh karena itu tuntutan dalam bentuk perbuatan melanggar hukum berdasarkan Pasal 1365 BW tidak mungkin untuk dilakukan. ${ }^{7}$

Menentukan bentuk hubungan antara Notaris dengan para penghadap harus dikaitkan dengan ketentuan Pasal 1869 BW, bahwa akta otentik terdegradasi menjadi pembuktian sebagai akta di bawah tangan dengan alasan: ${ }^{8}$

1. Tidak berwenangnya pejabat umum yang bersangkutan;

2. Tidak mampunya pejabat umum yang bersangkutan;

3. Cacat dalam bentuknya, atau karena Notaris dibatalkan berdasarkan Putusan Pengadilan yang telah mempunyai kekuatan hukum. Kemudian hal ini dapat dijadikan dasar untuk menggugat

\footnotetext{
6 ibid.

7 ibid., h. 101.

8 ibid., h. 102.
} 
Notaris sebagai suatu perbuatan melanggar hukum atau dengan kata lain hubungan Notaris dan para penghadap dapat dikualifikasikan sebagai perbuatan hukum, karena:

a) Notaris tidak berwenang membuat akta yang bersangkutan;

b) Tidak mampunya Notaris yang bersangkutan dalam membuat akta;

c) Akta Notaris cacat dalam bentuknya.

Gugatan terhadap Notaris dalam bentuk penggantian biaya, ganti rugi, dan bunga sebagai akibat akta Notaris mempunyai kekuatan pembuktian sebagai akta di bawah tangan atau batal demi hukum, berdasarkan adanya: ${ }^{9}$

1. Hubungan hukum yang khas antara Notaris dengan para penghadap dengan bentuk sebagai perbuatan melanggar hukum;

2. Ketidakcermatan, ketidaktelitian, dan ketidaktepatan dalam:

a) Teknik administratif membuat akta berdasarkan UUJN;

b) Penerapan berbagai aturan hukum yang tertuang dalam akta yang bersangkutan untuk para penghadap, yang tidak didasarkan pada kemampuan menguasai keilmuan bidang Notaris secara khusus dan hukum pada umumnya.

Sebelum Notaris dijatuhi sanksi perdata berupa penggantian biaya, ganti rugi, dan bunga, maka terlebih dahulu harus dibuktikan bahwa: ${ }^{10}$

1. Adanya diderita kerugian;

2. Antara kerugian yang diderita dan pelanggaran atau kelalaian dari Notaris terdapat hubungan kausal;

3. Pelanggaran (perbuatan) atau kelalaian tersebut disebabkan kesalahan yang dapat dipertanggungjawabkan kepada Notaris yang bersangkutan.

Selain dapat menjadi tergugat, Notaris juga dapat menjadi turut tergugat. Menurut Retnowulan Sutantio dan Iskandar Oeripkartawinata, dalam praktik, perkataan Turut Tergugat dipergunakan bagi orangorang yang tidak menguasai barang sengketa atau tidak berkewajiban untuk melakukan sesuatu, hanya demi lengkapnya suatu gugatan harus diikutsertakan.

\footnotetext{
9 ibid., h. 103.

${ }^{10}$ ibid., h. 104.
}

Mereka dalam petitum hanya sekedar dimohonkan agar tunduk dan taat terhadap putusan Hakim. ${ }^{11}$

Jadi, apabila seorang Notaris berkedudukan sebagai Turut Tergugat dalam suatu gugatan, ia hanya berkedudukan sebagai pelengkap saja. Notaris tersebut dijadikan Turut Tergugat agar gugatan menjadi lengkap, sehingga Turut Tergugat dapat dimohonkan agar tunduk dan taat terhadap Putusan, sedangkan pihak yang berkepentingan secara langsung adalah Penggugat dan Tergugat.

Berdasarkan penjabaran di atas maka dapat diketahui bahwa Notaris dapat digugat ganti rugi oleh para pihak penghadap ketika para pihak merasa dirugikan atas akta yang dibuat oleh Notaris. Gugatan bisa diajukan atas dasar hubungan hukum antara penghadap dengan Notaris dengan bentuk sebagai perbuatan melanggar hukum dan atas dasar ketidakcermatan, ketidaktelitian, dan ketidaktepatan Notaris dalam membuat akta serta penerapan berbagai aturan hukum yang tertuang dalam akta yang bersangkutan untuk para penghadap, yang tidak didasarkan pada kemampuan menguasai keilmuan bidang Notaris secara khusus dan hukum pada umumnya. Notaris juga dapat menjadi turut tergugat, tetapi dalam ini Notaris hanya sebagai pelengkap saja.

\section{Benda Terdaftar Sebagai Salah Satu Bentuk Perkembangan Yang Dibutuhkan Dalam Hukum Jaminan}

Menurut Pasal 499 BW, benda adalah tiap-tiap barang dan tiap-tiap hak, yang dapat dikuasai oleh hak milik. Seperti diketahui bahwa keberadaan benda dalam hamparan kehidupan manusia, secara matematis jumlahnya tak terhitung, demikian pula ragamnya sangat beraneka. Apa yang dibutuhkan manusia sendiri, mencakup pelbagai jenis benda yang tak mungkin lagi dipilah-pilah akibat sedemikian banyak kebutuhan yang harus dipenuhi. Dari segi kebutuhan dasar saja yakni sandang, pangan, dan papan, ditilik dari macam benda serta jumlahnya tidak kepalang tanggung rumitnya. Masih ditambah lagi, hasrat untuk melipatgandakan benda miliknya

${ }^{11}$ Retnowulan Sutantio dan Iskandar Oeripkartawinata. (1989). Hukum Acara Perdata Dalam Teori dan Praktek. Jakarta: Mandar Maju, h. 2. 
selalu diupayakan dari waktu ke waktu tanpa ada batas kapan mencapai garis akhirnya. ${ }^{12}$

Pengaturan oleh hukum terhadap benda yang bersosok tak terhingga dalam jumlah dan jenisnya, memerlukan kecermatan yang akurat. Untuk keperluan tersebut, hukum sebagai ilmu lalu mengawali aturannya dengan cara membagi-bagi benda ke dalam beberapa golongan secara berpasangpasangan. Kalau dicermati secara seksama, secara garis besar BW membagi benda menjadi beberapa golongan, menurut Moch. Isnaeni, pembagian tersebut yaitu: ${ }^{13}$

1. Benda berujud dan benda tidak berujud (Pasal $503 \mathrm{BW}$ );

2. Benda bergerak dan benda tidak bergerak (Pasal 504 BW);

3. Benda yang habis pakai dan benda yang tidak habis pakai (Pasal $505 \mathrm{BW}$ );

4. Benda yang sudah ada dan benda yang masih akan ada (Pasal $1131 \mathrm{BW}$ );

5. Benda yang dapat dibagi dan benda yang tidak dapat dibagi (Pasal 1160 jo 1163 BW);

6. Benda dalam perdagangan dan benda di luar perdagangan (Pasal $1332 \mathrm{BW}$ );

7. Benda yang dapat diganti dan benda yang tidak dapat diganti (Pasal 1694 BW);

8. Benda yang bertuan dan benda tidak bertuan (Pasal 519 BW).

BW mengenal demikian banyak pembagian jenis benda, namun dalam perkembangan masyarakat lebih lanjut menunjukkan kecenderungan adanya kehendak untuk menambah pembagian benda tersebut dengan jenis lain yang baru yakni benda terdaftar-benda tidak terdaftar. Gejala ini merebak setelah peristiwa kodifikasi BW, meskipun harus diakui bahwa pembagian benda bergerak dan benda tidak bergerak tetap diperlukan. Hal ini pernah pula diungkap oleh Sri Soedewi: Negara-negara Eropa Kontinental sejak resepsi Hukum Romawi hingga sekarang tetap menganggap penting arti pembedaan benda bergerak dan benda tidak bergerak. Meskipun disamping itu mulai dikenal juga pentingnya pembedaan benda terdaftar dan benda tak terdaftar (register goederen en niet register goederen), namun masih menganggap

\footnotetext{
${ }^{12}$ Moch. Isnaeni. (2016). Hukum Benda Dalam Burgelijk Wetboek. Surabaya: Revka Petra Media, h. 19.

${ }^{13}$ ibid., h. 20-21.
}

penting pembedaan antara benda bergerak dan benda tetap. ${ }^{14}$

Hal senada ditemui pula di Netherland sebab di samping tetap mempertahankan pembedaan jenis benda bergerak dan benda tidak bergerak, dalam BW barunya, mulai pula mencantumkan adanya benda terdaftar dan benda tidak terdaftar. Ini disinggung oleh Mariam dengan menyatakan bahwa Netherland dalam KUH Perdatanya yang baru, disamping tetap mempertahankan pendirian lama, yaitu mengenal pembedaan benda tetap dan bergerak, juga menambahkan pembedaan benda terdaftar dan tidak terdaftar. ${ }^{15}$

Pembagian atas benda terdaftar dan benda yang tidak terdaftar tidak dikenal, pembagian benda macam ini hanya dikenal beberapa waktu kemudian setelah BW dikodifikasikan dan diberlakukan. Benda-benda yang harus didaftarkan diatur dalam berbagai macam peraturan yang terpisah-pisah seperti peraturan tentang pendaftaran tanah, peraturan tentang pendaftaran kapal, peraturan tentang pendaftaran kendaraan bemotor, dan lain sebagainya. ${ }^{16}$

Pembagian benda yang baru secara khusus tidak dijumpai di BW menggulirkan problematika tentang bagaimana kedudukan hukumnya mengingat saat sekarang peran benda terdaftar kian menonjol. Menyangkut benda tidak terdaftar, gaungnya nyaris tak seberapa terasa karena masih kalah dominan dengan peran benda bergerak. Banyak sudah bendabenda kelengkapan hidup masyarakat moderen yang saat ini melibatkan keberadaan benda terdaftar seperti misalnya kendaraan bernotor, kapal laut, juga pesawat terbang. Jenis-jenis benda tersebut oleh masyarakat sudah sangat dibutuhkan kehadiran dan fungsinya untuk memutar roda kehidupan yang akselerasinya semakin berputar cepat. Banyak keuntungan dari benda terdaftar yang dimaksud saat melayani tuntutan kehidupan masyarakat moderen yang nampak berlaga adu cepat dengan pergerakan waktu. ${ }^{17}$

${ }^{14}$ Sri Soedewi Masjchoen Sofwan. (1980). Hukum Jaminan di Indonesia, Pokok-Pokok Hukum Jaminan dan Jaminan Perorangan. Yogyakarta: Liberty, h. 53.

${ }^{15}$ Mariam Darus Badrulzaman. (1983). Mencari Sistem Hukum Benda Nasional. Bandung: Alumni, h. 40.

${ }^{16}$ Soetan Malikoel Adil. (1962). Hak-Hak Kebendaan. Jakarta: Pembangunan, h. 53.

${ }^{17}$ Moch.Isnaeni, op.cit., h. 48. 
Eksistensi Hukum Perdata yang memiliki sifat luwes memudahkan untuk menyikapi persoalan tentang bagaimana kedudukan hukum benda terdaftar, sebab melalui pemanfaatan lembaga "analogi" kiranya dapat diatasi relatif mudah. Berdasarkan mekanisme penerapan analogi, maka ketentuan-ketentuan tentang benda tidak bergerak secara umum dapat diterapkan untuk mengatasi problema kedudukan hukum benda terdaftar. Baik menyangkut bidang levering, tanda bukti kepemilikan, bahkan lembaga jaminannya sekalipun dapat mempergunakan aturan dalam BW yang berlaku bagi benda bergerak dan tidak bergerak. Menyoal transaksi benda terdaftar dalam dunia bisnis, dapat diatasi relatif mudah dengan mempergunakan ketentuan yang berlaku untuk benda tidak bergerak yang ada dalam BW. Semisal menyangkut benda terdaftar berupa kendaraan bermotor, urusan balik nama ataupun tanda bukti kepemilikan dapat meniru apa yang berlaku untuk benda tidak bergerak. Kemapanan memakai mekanisme analogi, bahkan secara eksplisit ditegaskan oleh UU Pelayaran yang menentukan bahwa untuk kapal laut yang sudah terdaftar apabila hendak dijaminkan dipakailah jaminan Hipotek yang ada dalam BW. ${ }^{18}$

Berdasarkan penjabaran di atas, maka dapat diketahui bahwa pembagian baru mengenai benda terdaftar dan tidak terdaftar berpengaruh penting dalam pembebanan jaminan. Dalam pendaftaran pembebanan jaminan diperlukan kepastian hukum mengenai obyek jaminan. Pendaftaran terhadap suatu kebendaan ini dimaksudkan untuk menjamin kepastian hak kepemilikan atas benda-benda yang didaftarkan tersebut dan memudahkan negara untuk memungut pajak atas benda terdaftar tersebut.

\section{Akibat Hukum Terhadap Penjaminan Atas Sengketa Terhadap Obyek Jaminan}

Adakalanya dalam pembebanan jaminan terjadi sengketa terhadap obyek jaminan. Dalam hal ini tentunya berakibat hukum terhadap pembebanan jaminan tersebut. Sebagai pejabat umum yang berwenang untuk membuat akta otentik, Notaris tentunya juga bertanggung jawab atas apa yang ditulis didalam aktanya. Ketika obyek jaminan menjadi sengketa dan Putusan Pengadilan menyatakan bahwa kekuatan akta jaminan yang dibuat oleh Notaris

18 ibid., h. 49. menjadi kekuatan akta di bawah tangan, maka hal ini akan berakibat hukum kepada Notaris. Para pihak penghadap Notaris dapat menggugat Notaris dalam hal ganti rugi. Sanksi ini berupa penggantian biaya, ganti rugi, dan bunga merupakan akibat yang akan diterima Notaris atas tuntutan para penghadap.

Suatu akta yang batal demi hukum maka akta tersebut dianggap tidak pernah ada atau tidak pernah dibuat. Sesuatu yang tidak pernah dibuat tidak dapat dijadikan sebagai dasar suatu tuntutan dalam bentuk penggantian biaya, ganti rugi, dan bunga kepada para pihak yang tersebut dalam akta. ${ }^{19}$ Penggantian biaya, ganti rugi atau bunga dapat dituntut Notaris harus didasarkan pada suatu hubungan hukum antara Notaris dengan para pihak yang menghadap Notaris. Jika ada pihak yang merasa dirugikan sebagai aibat langsung dari suatu akta Notaris, maka yang bersangkutan dapat menuntut secara perdata terhadap Notaris. Dengan demikian, tuntutan ganti biaya, ganti rugi dan bunga terhadap Notaris tidak berdasar atas penilaian atau kedudukan suatu alat bukti yang berubah karena melanggar ketentuan tertentu menurut Pasal 84 UUJN, tapi hanya didasarkan pada hubungan hukum yang ada atau yang terjadi antara Notaris dengan para penghadap. ${ }^{20}$

Selain berakibat hukum terhadap Notaris, penjaminan obyek jaminan yang bersengketa juga berakibat hukum terhadap kreditor. Dalam hal ini kreditor sangat berperan langsung pada penjaminan. Ketika debitor melakukan wanprestasi, maka kreditor harus melakukan sita jaminan. Dan apabila obyek jaminan tersebut disengketakan otomatis kreditor terhalang untuk melakukan sita jaminan. Akan tetapi dalam hal ini terdapat dua perlindungan hukum bagi kreditor, yakni perlindungan preventif dan perlindungan represif. Perlindungan hukum preventif terdiri atas: ${ }^{21}$

1. Pasal 1131 dan $1132 \mathrm{BW}$, mengenai segala kebendaan debitur baik yang bergerak maupun yang tidak bergerak, baik yang telah ada maupun yang akan ada, nantinya menjadi tanggungan untuk segala perikatannya, serta kebendaan atau

\footnotetext{
19 ibid.

20 ibid., h. 92.
}

21 Arista Nurul Shofa, Suhariningsih, dan Amelia Sri Kusuma. (2014). Perlindungan Hukum bagi Kreditor atas Sengketa Jaminan yang dibebani Tanggungan. Kumpulan Jurnal Mahasiswa, Serial Online, hukum.studentjournal.ub.ac. id, diakses pada tanggal 19 Oktober 2018, pukul 13.00, h. 10. 
obyek yang dijaminkan tersebut menjadi jaminan bersama bagi semua orang yang mengutang padanya. Maka menurut penulis, berdasarkan Pasal 1131 dan 1132 BW kreditur mendapatkan perlindungan hukum untuk mendapatkan pelunasan kreditnya dari debitur. Sehingga tidak dipusatkan pada obyek sengketa yang digunakan untuk melunasi utang debitur, namun harta lain juga bias menjadi jaminan bagi kreditur untuk mendapatkan pelunasan piutang;

2. Undang-Undang Nomor 10 Tahun 1998 Perubahan Atas Undang-Undang Nomor 7 Tahun 1992 tentang Perbankan menurut Pasal 12a, apabila debitur mengalami kredit macet, bank dapat membeli sebagian atau seluruh agunan, baik melalui pelelangan umum maupun di luar pelelangan berdasarkan penyerahan secara sukarela oleh pemilik agunan atau berdasrkan kuasa untuk menjual di luar lelang dari pemilik agunan dalam hal nasabah debitur tidak memenuhi kewajibannya kepada bank, dengan ketentuan agunan yang dibeli tersebut wajib dicairkan secepatnya. Pembelian agunan oleh bank melalui pelelangan dimaksudkan untuk membantu bank agar dapat mempercepat penyelesaian kewajiban nasabah debiturnya;

3. Pasal 1 ayat (1) UUHT memberikan kedudukan yang diutamakan atau didahulukan kepada pemegang Hak Tanggungan atau kreditur (droit de preference), merupakan salah satu wujud perlindungan hukum yang diberikan bagi pihak kreditur apabila terjadi wanprestasi dari debitur, khususnya dalam pengambilan pelunasan piutangnya.

Perlindungan hukum represif terdiri atas: ${ }^{22}$

1. Dalam Pasal 6, 7, 11, 14, 20 UUHT yang mengatur mengenai apabila debitur cidera janji, maka pemegang Hak Tanggungan pertama mempunyai hak untuk menjual obyek Hak Tanggungan atas kekuasaan sendiri melalui pelelangan umum serta mengambil pelunasan piutangnya dari hasil penjualan tersebut. Dimana jaminan yang dijadikan obyek Hak Tanggungan harus didaftarkan dan mendapatkan Sertifikat Hak Tanggungan yang memiliki irah- irah "Demi Ketuhanan Yang Maha Esa”, maka memiliki

\footnotetext{
22 ibid., h. 11
}

kekuatan eksekutorial bagi pemegang Hak Tanggungan;

2. Menurut Pasal 1865 dan 1866 BW, setiap orang yang mendalilkan bahwa ia mempunyai suatu hak, atau guna meneguhkan haknya sendiri maupun membantah suatu hak pihak ketiga, menunjuk pada suatu peristiwa, diwajibkan membuktikan adanya hak atau peristiwa tersebut, dengan alat bukti berupa bukti tulisan, bukti dengan saksi-saksi, persangkaan-persangkaan, pengakuan, serta sumpah. Maka, menurut penulis, kreditur dapat melakukan pembuktian sesuai pasal tersebut dengan mengajukan buktibukti tulisan berupa akta atau sertifikat dari perjanjian awal kredit sampai pada kepemilikan sertifikat Hak Tanggungan, mengajukan saksisaksi, dan lain sebagainya.

Manakala akta jaminan yang merupakan akta otentik tidak terdegradasi menjadi akta di bawah tangan, sudah barang tentu lembaga jaminan tidak dapat mempertahankan penjaminannya, dalam arti penegakan sifat-sifat lembaga jaminan sebagai berikut ini tidak akan bisa tercapai: ${ }^{23}$

1. Hak jaminan itu bersifat mutlak, artinya hak tersebut dapat ditekankan pada siapapun, di mana hak itu tidak hanya dapat ditegakkan terhadap pihak rekan seperjanjian saja, tetapi juga kepada pihak ketiga yang bukan mitra pembangun sepakat sekalipun;

2. Dalam hak jaminan kebendaan ada ciri droit de suite, artinya bahwa hak tersebut akan selalu mengikuti bendanya kemanapun benda itu berada. Apabila pada sebuah benda diatasnya dilekati hak kebendaan bercorak jaminan, maka jenis hak tersebut akan tetap menempel meski benda yang bersangkutan jatuh dan dikuasai oleh pihak lain;

3. Dalam hak jaminan kebendaan ada asas prioritas, artinya bahwa hak kebendaan yang lahir lebih dahulu akan diutamakan daripada yang kemudian;

4. Dalam hak jaminan kebendaan ada asas preferensi, maknanya bahwa kreditor pemegang jaminan hak kebendaan piutangnya harus dilunasi terlebih dahulu dari kreditor lain;

${ }^{23}$ Moch. Isnaeni. (2016). Pengantar Hukum Jaminan Kebendaan. Surabaya: Revka Petra Media, h. 136-157. 
5. Dalam hak jaminan kebendaan ada asas publisitas, artinya bahwa hak kebendaan tersebut memerlukan suatu perbuatan hukum khusus yang wajib dilakukan sehingga umum atau masyarakat mengetahui keberadaan hak kebendaan yang bersangkutan;

6. Dalam hak jaminan kebendaan ada asas totalitet, artinya bahwa hak jaminan kebendaan itu menindih keseluruhan benda yang bersangkutan secara utuh, bukannya sebagian demi sebagian;

7. Bahwa jaminan kebendaan dilekati sifat tidak dapat dibagi-bagi, artinya dengan dilunasinya sebagian utang oleh debitor, bukan berarti sebagian dari benda dijaminkan itu menjadi terbebaskan karenanya;

8. Dalam hak jaminan kebendaan ada asas spesialitas, artinya suatu benda yang diikat dengan perjanjian jaminan kebendaan, ciricirinya harus ditetapkan secara tegas;

9. Hak jaminan kebendaan memberikan sistem eksekusi agunan yang mudah. Apabila debitor wanprestasi, kreditor punya kewenangan untuk melaksanakan eksekusi agunan yang mudah, sederhana, serta cepat, dan itu antara lain dengan menggunakan lembaga hukum parate eksekusi. Hal ini disebabkan karena sifat-sifat lembaga jaminan tersebut hadir manakala proses penjaminannya sah. Sedangkan sahnya suatu proses penjaminan adalah didaftarkan, dan untuk pendaftaran jaminan tersebut, terdapat beberapa ketentuan, antara lain adalah prinsip Nemo Plus Iuris yaitu orang tidak dapat mengalihkan hak melebihi hak yang ada padanya. ${ }^{24}$

Berdasarkan penjabaran di atas maka dapat diketahui bahwa ketika terjadi sengketa pada obyek jaminan maka keontentikan akta Notaris dapat terdegradasi nilai pembuktiannya menjadi akta dibawah tangan karena akta tersebut dinilai tidak sesuai dengan ketentuan. Hal ini menyebabkan syarat sah dari pendaftaran penjaminan tidak sah dan pembebanan jaminan itu dianggap tidak pernah ada. Hal ini menyebabkan kerugian terhadap para pihak yang menghadap Notaris khususnya kreditor. Atas kerugian ini Notaris dapat digugat ganti rugi atas dasar perbuatan melanggar hukum.

\footnotetext{
${ }^{24}$ Adrian Sutedi. 2010. Peralihan Hak Atas Tanah dan
} Pendaftarannya. Jakarta: Sinar Grafika, h. 117.

\section{PENUTUP}

\section{Kesimpulan}

Notaris harus bertanggung gugat atas akta yang telah dibuatnya. Notaris dapat digugat ganti rugi oleh para pihak penghadap ketika para pihak merasa dirugikan atas akta yang dibuat oleh Notaris. Pembagian baru mengenai benda terdaftar dan tidak terdaftar berpengaruh penting dalam pembebanan jaminan. Pendaftaran terhadap suatu kebendaan ini dimaksudkan untuk menjamin kepastian hak kepemilikan atas benda-benda yang didaftarkan tersebut dan memudahkan negara untuk memungut pajak atas benda terdaftar tersebut. Ketika terjadi sengketa pada obyek jaminan maka keontentikan akta Notaris dapat terdegradasi nilai pembuktiannya menjadi akta di bawah tangan. Hal ini menyebabkan syarat sah dari pendaftaran penjaminan tidak sah dan pembebanan jaminan itu dianggap tidak pernah ada. Hal ini menyebabkan kerugian terhadap para pihak yang menghadap Notaris khususnya kreditor. Atas kerugian ini Notaris dapat digugat ganti rugi atas dasar perbuatan melanggar hukum.

\section{Rekomendasi}

Notaris dalam pekerjaannya membuat suatu akta otentik, juga diwajibkan untuk membuktikan atau verifikasi bahwa bukti kepemilikan objek yang dijaminkan itu benar sah dan tidak ada potensi bukti kepemilikan ganda.

\section{DAFTAR PUSTAKA}

\section{Peraturan Perundang-undangan:}

Burgerlijk Wetboek.

Undang-Undang Nomor 4 Tahun 1996 tentang Hak Tanggungan.

Undang-Undang Nomor 10 Tahun 1998 Perubahan Atas Undang-Undang Nomor 7 Tahun 1992 tentang Perbankan.

Undang-Undang Nomor 2 Tahun 2014 tentang Perubahan Atas Undang-Undang Nomor 30 Tahun 2004 tentang Jabatan Notaris.

\section{Buku:}

Adrian Sutedi. (2010). Peralihan Hak Atas Tanah dan Pendaftarannya. Jakarta: Sinar Grafika.

Arista Nurul Shofa, Suhariningsih, dan Amelia Sri Kusuma. (2014). "Perlindungan Hukum bagi Kreditor atas Sengketa Jaminan yang dibebani 
Tanggungan". Kumpulan Jurnal Mahasiswa, Serial Online, hukum.studentjournal.ub.ac.id, diakses pada tanggal 19 Oktober 2018, pukul 13.00 .

Habib Adjie. (2015). Tafsir Tematik Hukum Notaris Indonesia berdasarkan Undang-Undang Nomor 2 Tahun 2014 tentang Jabatan Notaris. Bandung: Refika Aditama. (2017). Sanksi Perdata dan Administratif Terhadap Notaris sebagai Pejabat Publik. Bandung: Refika Aditama.

Mariam Darus Badrulzaman. (1983). Mencari Sistem Hukum Benda Nasional. Bandung: Alumni.
Moch. Isnaeni. (2016). Hukum Benda Dalam Burgelijk Wetboek. Surabaya: Revka Petra Media.

(2016). Pengantar Hukum Jaminan Kebendaan. Surabaya: Revka Petra Media.

Retnowulan Sutantio dan Iskandar Oeripkartawinata. (1989). Hukum Acara Perdata Dalam Teori dan Praktek. Jakarta: Mandar Maju.

Soetan Malikoel Adil. (1962). Hak-Hak Kebendaan. Jakarta: Pembangunan.

Sri Soedewi Masjchoen Sofwan. (1980). Hukum Jaminan di Indonesia, Pokok-Pokok Hukum Jaminan dan Jaminan Perorangan. Yogyakarta: Liberty. 